\title{
石羊河流域全新世抱粉记录及其对气候系统 响应争论的启示
}

\author{
李育，王乃昂，李卓仑，张华安 \\ 兰州大学资源环境学院, 兰州 730000 \\ E-mail: liyu@1zu.edu.cn
}

2010-08-10 收稿, 2010-11-09 接受

国家自然科学基金(41001116, 50879033)和兰州大学中央高校基本科研业务费专项资金(1zujbky-2010-99)资助项目

\begin{abstract}
摘要 石羊河流域位于亚洲季风西北边缘区, 已有的全新世气候变化研究结果之间存在较大分 歧。一些研究提出该区域全新世气候变化主要受控于亚洲季风, 早全新世气候较湿润(11.6 7.1 cal ka BP); 另一些研究则提出湿润期发生于中全新世气候适宜期(7.0 5.0 cal ka BP), 与中亚干 旱区全新世气候变化西风模式相似. 石羊河流域现代气候受亚洲季风和西风带气流的共同影 响, 古气候记录却显示了两种不同的全新世气候模式一一季风气候模式和西风模式. 究竟是什 么原因导致两种截然不同的气候模式共存于一个区域? 本文选择石羊河流域终端湖猪野泽的 QTH02, QTL-03 和三角城剖面及石羊河中游地区红水河剖面开展全新世孢粉学对比研究, 以期 全面认识这一问题。研究发现猪野泽地区 QTH02 和 QTL-03 剖面全新世孢粉记录相似度高, 三 角城剖面中全新世狍粉记录与上述两剖面差异较大, 但这一差别主要受控于湖泊不同位置孢粉 组合的差异. 根据这 4 个全新世孢粉记录的综合分析, 发现石羊河流域全新世期间在千年尺度 上受到亚洲季风与西风带气流的共同影响，体现了季风模式和西风模式的共同特点.
\end{abstract}

关键词

全新世 亚洲季风 西风模式 季风边缘区 孢粉记录
2009 年过去全球变化研究计划 PAGES(Past Global Changes)发布了最新科学计划和实施策略, 其 4 个主题之一的区域气候动力学将全新世列为 3 个重点研究时段之一, 说明全新世研究将更加受到 重视 ${ }^{[1]}$. 我国全新世气候变化存在一定复杂性, 不同 区域全新世气候变化过程可能存在差异 ${ }^{[2]}$. An 等人 ${ }^{[3]}$ 首先提出了我国亚洲季风区全新世气候变化的不同 步问题; 2006 年 $\mathrm{An}$ 等人 ${ }^{[4]}$ 发现我国干旱-半干旱区中 全新世期间存在千年尺度的干旱事件，但是这些干 旱事件在不同区域发生的时间并不相同, 同时, 来 自黄土高原西部的记录却显示了中全新世期间气候 较为湿润 ${ }^{[5]}$, 这些均说明我国干旱-半干旱地区全新 世气候变化具有复杂性. 我国亚洲季风又可以分为 东亚季风和印度季风两个子系统 ${ }^{[6,7]}$, Hong 等人 ${ }^{[8]}$ 根
据东亚季风区和印度季风区的全新世泥炭对比研究, 提出了全新世期间亚洲季风区两个子系统之间气候 变化存在反相位的关系. 后来, 杨琰等人 ${ }^{[9]}$ 根据亚洲 季风区石笋记录区域对比, 对这种观点提出质疑.

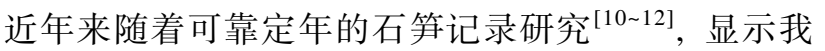
国亚洲季风区全新世气候变化具有一定同步性，亚 洲季风降水在早全新世期间达到峰值并开始下降. 但是目前为止全新世石笋记录研究点在我国季风区 的分布具有一定局限性，所以其显示的全新世亚洲 季风同步演化的结果，还有待更多可靠定年记录证 实. 我国西北地区气候受亚洲季风系统和西风带气 流的共同影响 ${ }^{[13]}, 1990$ 年李吉均院士 ${ }^{[14]}$ 首先提出了 我国西北地区晚更新世以来千年尺度的“季风”和“西 风”模式，将我国西北地区分为服从西风带一般规律

英文版见: Li Y, Wang N A, Li Z L, et al. Holocene palynological records and their responses to the controversies of climate system in the Shiyang River drainage basin. Chinese Sci Bull, 2011, 56, doi: 10.1007/s11434-010-4277-y 
的新疆地区, 和受季风影响的甘肃、青海等地区. 后 来随着第四纪科学的发展, Herzschuh ${ }^{[15]}$ 综述了 75 个 东亚、中亚地区的古气候记录, 提出中亚地区和亚洲 季风区的部分区域全新世气候演化模式具有差异. Chen 等人 ${ }^{[16]}$ 综述了亚洲季风区和中亚西风带控制区 具可靠定年的全新世记录, 提出亚洲季风区和中亚 干旱区全新世千年尺度气候变化模式并不相同, 这 主要受控于亚洲季风和西风带气流全新世演化模式 不同, 并在此基础上提出了千年尺度上全新世气候 变化的西风模式和季风模式. 这里的季风模式, 与 现代气候学的气候模式不同, 指千年尺度亚洲季风 区早全新世较湿润, 中全新世开始出现干旱化趋势 的一种气候变化形式. 同理, 西风模式指中亚西风 带控制区，在千年尺度上中、晚全新世气候较湿润的 一种气候变化形式(本文在后面的讨论部分会涉及到 一些季风模式和西风模式的内容, 基于上述定义, 本文所提到的季风模式和西风模式均为全新世千年 尺度气候变化的形式, 只能用来探讨大尺度的气候 变化格局, 并不能用来区分年际及十年际尺度的气 候系统的相互所用). 研究亚洲季风边缘区全新世气 候变化过程, 可以进一步探讨亚洲季风和西风带气 流的相互作用机制. 我国已有的亚洲季风边缘区不 同位置全新世气候变化研究结果差异较大 ${ }^{[17 \sim 20]}$, 了 解季风边缘区不同位置全新世气候变化过程的差异, 对于研究全新世季风与西风相互作用机制具有重要 意义.

我国干旱-半干旱区全新世狍粉记录主要用于 重建古植被及古生态状况 ${ }^{[21 ~ 24]}$, 而古植被及古生态 状况主要受控与该区域的气候条件, 所以通过流域 性的狍粉记录可以重建该区域全新世期间的气候状 况. 石羊河流域位于亚洲季风西北边缘区(图 1), 该 流域与中亚西风带控制区较近。根据已有研

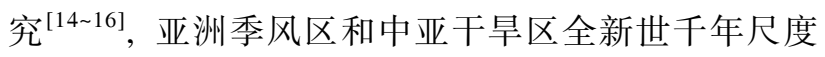
气候变化模式并不相同. 根据石羊河流域的全新世 狍粉记录重建气候变化过程, 对比其气候变化过程 与亚洲季风区和中亚干旱区的异同, 可以了解该流 域全新世气候主要受“季风”还是“西风”模式影响. 本研究小组 $\mathrm{Li}$ 等人 ${ }^{[21,22]}$ 根据石羊河流域终端湖泊 ——猪野泽的全新世湖泊沉积物研究, 提出该区域 全新世气候适宜期出现在中全新世 7.4 4.7 cal ka BP 期间. Zhao 等人 ${ }^{[23]}$ 根据猪野泽中部全新世狍粉组合 研究, 也得出全新世气候适宜期出现在中全新世

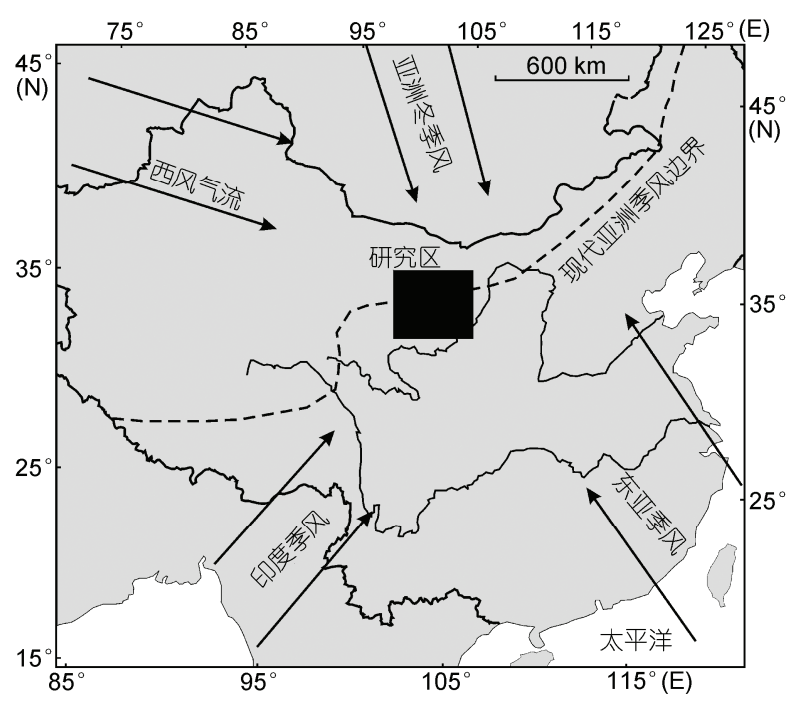

图 1 研究区位置示意图

图中虚线表示现代亚洲季风在我国的边界, 箭头指示了影响我国的 主要气候系统, 包括东亚季风、印度季风、亚洲冬季风、西风气流 ${ }^{[13,26]}$

7.2 5.2 cal ka BP 期间的认识. 两研究均显示该流域 全新世气候变化与中亚干旱区西风模式相近. 但 Chen 等人 ${ }^{[24,25]}$ 根据猪野泽西部的三角城剖面全新世 沉积物研究, 得出该流域全新世气候主要受控于亚 洲季风, 早全新世 11.0 7.0 cal ka BP 期间降水量较 多，为全新世气候适宜期，中全新世期间该流域气 候比较干旱. 是什么原因导致同一研究区不同地点 得出两种完全不同的全新世气候变化模式? 孢粉研 究是该流域全新世气候变化研究的一种重要方法, 本文选择了石羊河流域不同位置的 4 个全新世狍粉 记录进行对比分析, 来探讨该流域全新世气候变化 模式.

\section{1 研究区概况}

石羊河流域位于甘肃省河西走廊东部, 祁连山 北麓, 地理坐标大体介于 $100^{\circ} 57^{\prime} \sim 104^{\circ} 57^{\prime} \mathrm{E}, 37^{\circ} 02^{\prime}$ $39^{\circ} 17^{\prime} \mathrm{N}$, 流域全长 300 余公里, 总面积 $4.16 \times 10^{4} \mathrm{~km}^{2}$ (图 2). 按我国自然地理区划, 石羊河流域处于我国 西北内陆干旱区与东部季风区的交汇过渡地带, 现 代气候受亚洲季风与西风带气流的共同影响 ${ }^{[26]}$. 根 据现代气候学研究, “盛行西风”和“西风急流”共同组 成的西风带气流对我国西北地区水汽输送贡献较大, 和亚洲季风共同影响着季风边缘区的气候系统 ${ }^{[27,28]}$. 东亚高空西风急流的变化对我国东部夏季雨带的变 


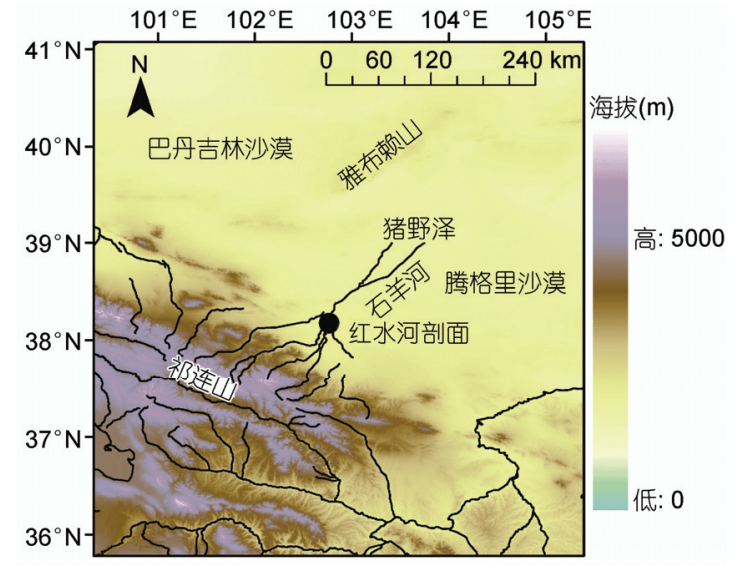

图 2 猪野泽、石羊河流域及周围区域高程示意图 黑色实心圆显示了石羊河中游地区红水河剖面的位置

化 ${ }^{[29]}$ 、梅雨期降水空间分布 ${ }^{[30]}$ 和东亚冬季风 ${ }^{[31]}$ 的强 度均有一定影响, 是影响我国的一支主要气流. “盛 行西风”和“西风急流”对我国气候系统的影响机理不 同. 但由于本文研究焦点集中在千年尺度, 而不是 年际和十年际尺度, 现有古环境记录的指示性和分 辨率也很难区分这两种西风带气流, 所以本文将“盛 行西风”和“西风急流”综合为西风带气流.

石羊河流域自南向北大致划分为 3 个气候区. 南部祁连山高寒半干旱湿润区: 海拔 2000 5000 m, 年降水量 300 600 mm, 年蒸发量 700 1200 mm, 植
被分为高山垫状植被带(代表性植物有垫状点地梅 (Androsace tapete)、垫状驼线藜(Ceratoides compacta) 等)、高山草甸带(代表性植物有嵩草属(Kobresia)等)、 高山灌丛带 (代表性植物有杜鹃花属 (Rhododendron)、金露梅(Potentilla fruticosa) 等)、森林带(代表 性植物有云杉(Picea)、圆柏(Sabina)、杨属(Populus)、 桦属(Betula) 等)、山前草甸草原带(短花针茅(Stipa breviflora)芨芨草(Achnatherum splendens) 等); 中部 平原温凉干旱区: 海拔 1500 2000 m, 年降水量 150 300 mm, 年蒸发量 1300 2000 mm, 为荒漠草原 带(以禾本科(Poaceae)为主, 伴有旱生半灌木、灌木); 北部温暖干旱区: 海拔 1300 1500 m, 年降水量小于 $150 \mathrm{~mm}$, 年蒸发量 2000 2600 mm, 植被为荒漠植被 (代表性植物有梭梭(Haloxylon ammodendion)、白刺 (Nitraria)、膜果麻黄 (Ephedra przewalskii) 等 $)^{[32,33]}$. 猪野泽是石羊河流域的终端湖泊, 历史时期湖泊水 位较高 ${ }^{[34,35]}$, 现在已经完全干涸. Pachur 等人 ${ }^{[36]}$ 、 Zhang 等人 ${ }^{[37,38]}$ 和本研究小组 ${ }^{[39]}$ 分别研究了猪野泽 地区晚更新世湖泊地貌演化, 并测定了猪野泽东北 部古湖岸堤的年代. 综合上述研究结果，早、中全新 世猪野泽湖泊水位较高, 晚全新世湖泊水位较低. 猪野泽是由白碱湖、东硝池、西硝池、野麻湖和青 土湖等小湖盆组成(图 3), 但是根据野外考察并结合 地形图分析, 各个小湖盆之间都有水道相连接, 所

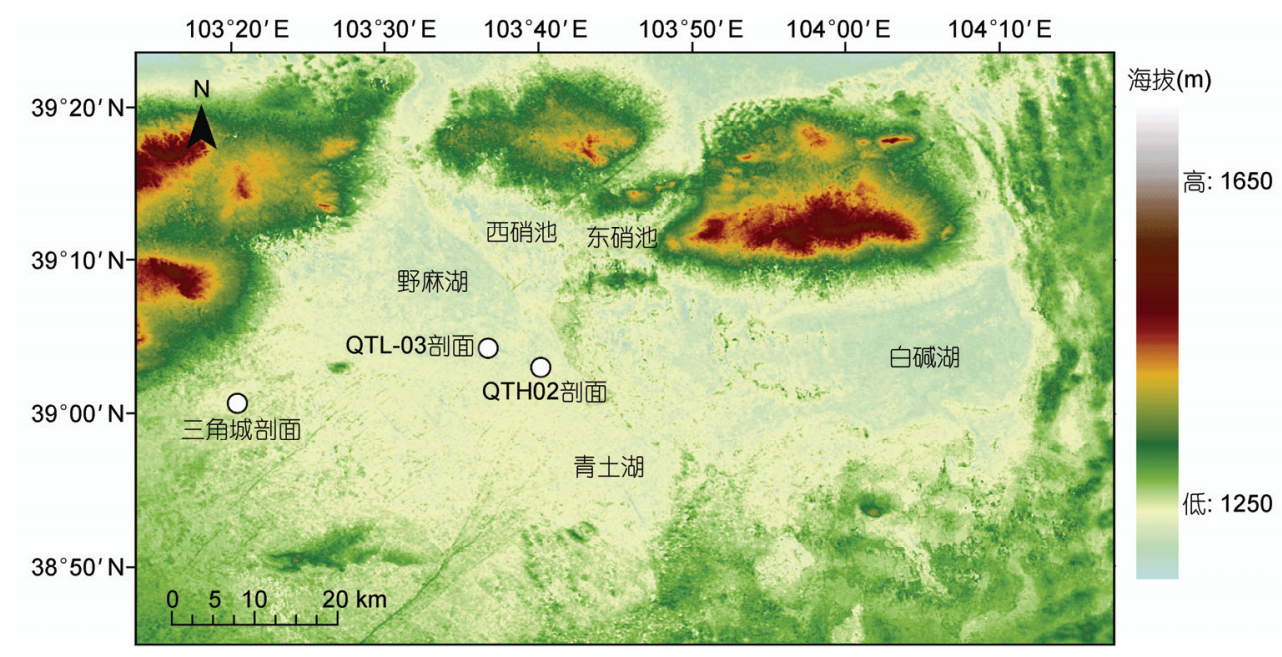

图 3 猪野泽湖盆经纬度及高程示意图

白碱湖、野麻湖、青土湖、西硝池、东硝池等为猪野泽子湖盆. 白色实心圆显示了 QTH02, QTL-03 和三角城剖面. 图中高程数据来自于 $30 \mathrm{~m}$ 精度的 ASTER-GDEM 数据, 下载于 https://wist.echo.nasa.gov/wist-bin/api/ims.cgi?mode=MAINSRCH\&JS=1 
以猪野泽中全新世期间各个小湖盆的湖泊水位基本 一致.

\section{2 剖面及年代}

QTH01 和 QTH02 剖面为本研究小组在猪野泽中 部开挖的全新世剖面, 两个剖面相距 $80 \mathrm{~m}$, 海拔 $1309 \mathrm{~m}$, 地理坐标为 $39^{\circ} 03^{\prime} 00^{\prime \prime} \mathrm{N}, 103^{\circ} 40^{\prime} 08^{\prime \prime} \mathrm{E}$ (图 3), 年代由两个剖面根据岩性和粒度组成互相内插得 出 ${ }^{[21,22]}$, 孢粉样品采自 QTH02 剖面. QTL-03 剖面 ${ }^{[23]}$ 地理坐标为 $39^{\circ} 04^{\prime} 15^{\prime \prime} \mathrm{N}, 103^{\circ} 36^{\prime} 43^{\prime \prime} \mathrm{E}$, 海拔 $1302 \mathrm{~m}$ (图 3); 三角城剖面 ${ }^{[24,25]}$ 地理坐标为 $39^{\circ} 00^{\prime} 38^{\prime \prime} \mathrm{N}$, $103^{\circ} 20^{\prime} 25^{\prime \prime} \mathrm{E}$, 海拔 $1320 \mathrm{~m}$ (图 3). 红水河剖面 ${ }^{[40,41]}$ 位 于石羊河中游地区红水河阶地上, 海拔高度 $1460 \mathrm{~m}$
(图 2). 红水河剖面由红水河全新世剖面和红水河晚 冰期-早全新世剖面 $\left(38^{\circ} 10^{\prime} 46^{\prime \prime} \mathrm{N}, 102^{\circ} 45^{\prime} 53^{\prime \prime} \mathrm{E}\right)$ 组成, 两剖面相距 $1 \mathrm{~km}$, 基于两个剖面的位置、地表侵蚀 状况和沉积物的年代, 将两剖面拼接起来, 可以得 到连续的全新世沉积记录. 红水河两剖面位于石羊 河中游地区，其沉积相主要受控于石羊河流域中、 上游地区的环境状况, 降水较多、气候湿润期, 形 成湖相和泥炭沉积地层, 气候干燥时期以砂层沉积 为主 ${ }^{[40,41]}$. 图 4 显示了 QTH01, QTH02, QTL-03, 三 角城和红水河剖面的沉积物岩性及年代测定结果. 该流域全新世沉积物年代测定主要采用 ${ }^{14} \mathrm{C}$ 测年法, 湖泊沉积物 ${ }^{14} \mathrm{C}$ 测年会受到碳库效应影响, 本研究 小组在河西走廊中段花海古湖泊测得了 2500 年左右

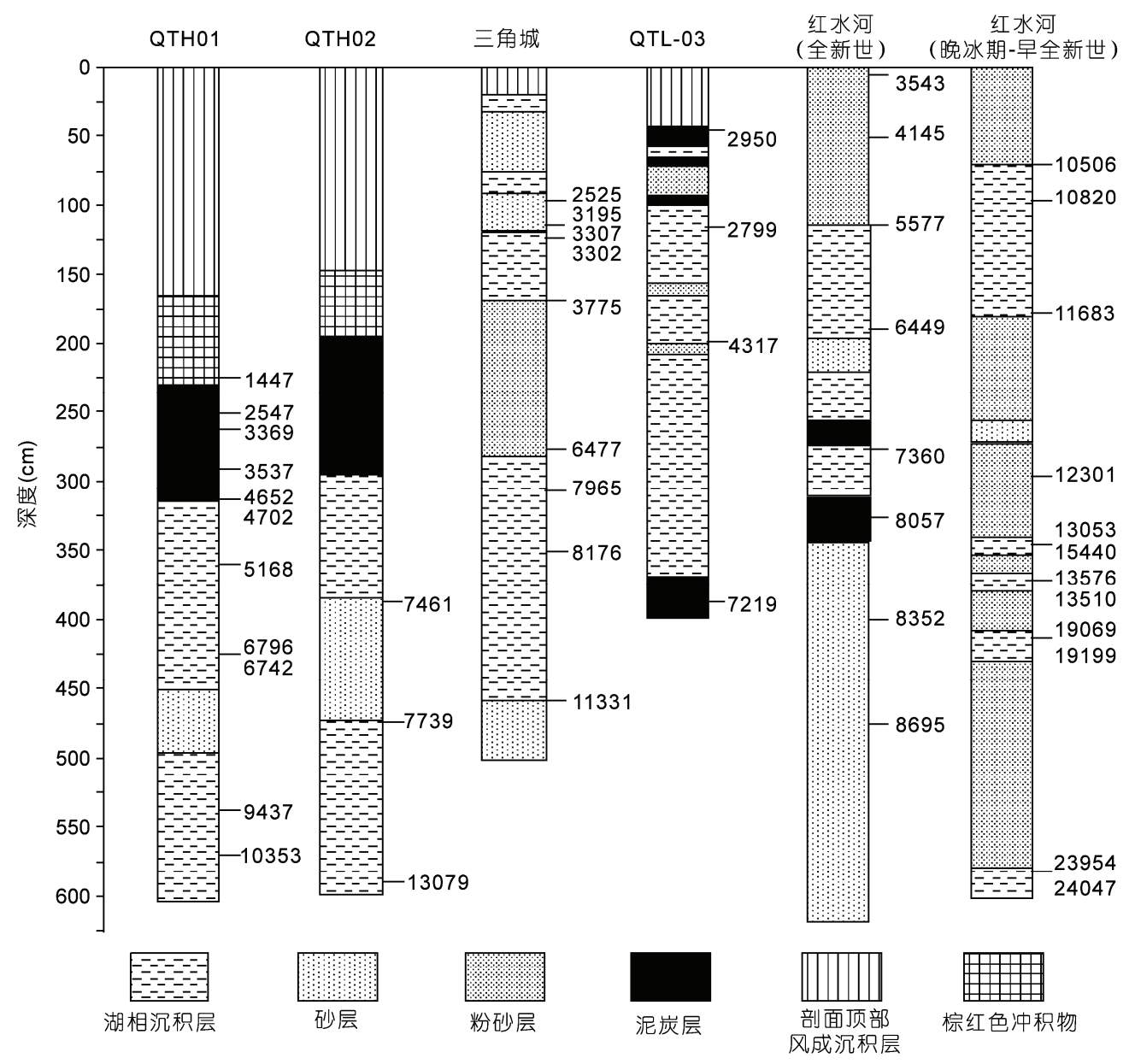

图 4 QTH01 ${ }^{[21,22]}, \mathrm{QTH} 02^{[21,22]}, \mathrm{QTL}-03^{[23]}$, 三角城 ${ }^{[24]}$ 及红水河剖面 ${ }^{[40,41]}$ (分为全新世和晚冰期-早全新世两个剖面)岩性 及测年结果示意图

剖面旁的数字为年龄, 单位: cal a BP. 图中所示的 ${ }^{14} \mathrm{C}$ 测年结果均为经过树轮程序校正的日历年. ${ }^{14} \mathrm{C}$ 年代校正程序采用 Calib5.01 
的碳库效应 ${ }^{[42]}$. 为了了解猪野泽全新世沉积物的碳 库效应, 本研究小组在研究猪野泽 QTH01 全新世剖 面时, 分别在 315 和 $425 \mathrm{~cm}$ 深度采集了两套样品进 行 $14 \mathrm{C}$ 测年. 埋深 $315 \mathrm{~cm}$ 处全样有机质年代为 $(4130 \pm 110) a$ ，壳体 AMS $14 \mathrm{C}$ 年代为 $(4160 \pm 40) \mathrm{a}$; 埋 深 $425 \mathrm{~cm}$ 处全样碳酸盐年代为 $(5960 \pm 65) \mathrm{a}$, 壳体 AMS ${ }^{14} \mathrm{C}$ 年代为 $(5920 \pm 40) \mathrm{a}^{[21]}$. QTH01 剖面全样有 机质 ${ }^{14} \mathrm{C}$ 测年结果和螺壳 AMS $14 \mathrm{C}$ 测年结果也几乎 相同, 据此认为此区域碳库效应很小. 同时, 根据 陈发虎等人 ${ }^{[43]}$ 对猪野泽地区三角城剖面“碳库效应” 的研究, 该区域仅存在 550 年左右的碳库效应, 也 表明该区域碳库效应较小. 本项研究主要探讨千年 尺度上的全新世气候变化模式, 根据以上研究结果 该区域的碳库效应不会影响本文的研究。根据 Zhang 等人 ${ }^{[40]}$ 的报道, 红水河剖面部分年代采用陆 生植物残体 (树枝或树根残体)测定, 根据对比植物 残体与其上部年代的差异, 发现石羊河中游地区全 新世沉积地层碳库效应也比较小, 测年结果比较可 靠. 以上研究表明, 本研究的 QTH01, QTH02, QTL-03, 三角城和红水河剖面全新世沉积物受碳 库效应影响较小, 其测年误差不会影响本文探讨全
新世千年尺度的气候模式.

\section{3 石羊河流域全新世狍粉记录}

\subsection{QTH02 剖面全新世狍粉组合}

QTH02 剖面位于猪野泽中部(图 3), 剖面孢粉分 析和年代测定由本研究小组完成. 该剖面以 $10 \mathrm{~cm}$ 间隔采样共采得孢粉样品 74 个, 多数样品统计 500 粒以上, 狍粉较少的层位统计 100 粒以上. 全新世期 间该剖面孢粉组合主要分为 $\mathrm{A}, \mathrm{B}, \mathrm{C}$ 三个孢粉带(图 5). 带 $\mathrm{A}(11.0 \sim 7.4$ cal ka BP $)$, 草本植物花粉百分比 在 43\% 97\%之间，其中高属(Artemisia)所占的比例 最大, 平均为 $72 \%$. 乔木花粉的百分含量达到全新世 期间的最高值, 平均为 $14 \%$, 其中针叶树松属(Pinus) 和云杉属是乔木花粉的主要组成部分. 该段总狍粉 浓度在 80 209 grains/g 之间. 带 B(7.4 4.7 cal ka BP), 狍粉浓度相对于早全新世大幅度增加, 平均为 38634 grains/g. 蒿属花粉平均为 $76 \%$, 藜科 (Chenopodiaceae)花粉含量平均为 $13 \%$. 乔木花粉百分比含量较 低，但狍粉浓度达到了全新世的最高值 1232 grains $/ \mathrm{g}$. 其中云杉花粉的浓度为 $382 \mathrm{grains} / \mathrm{g}$, 是全

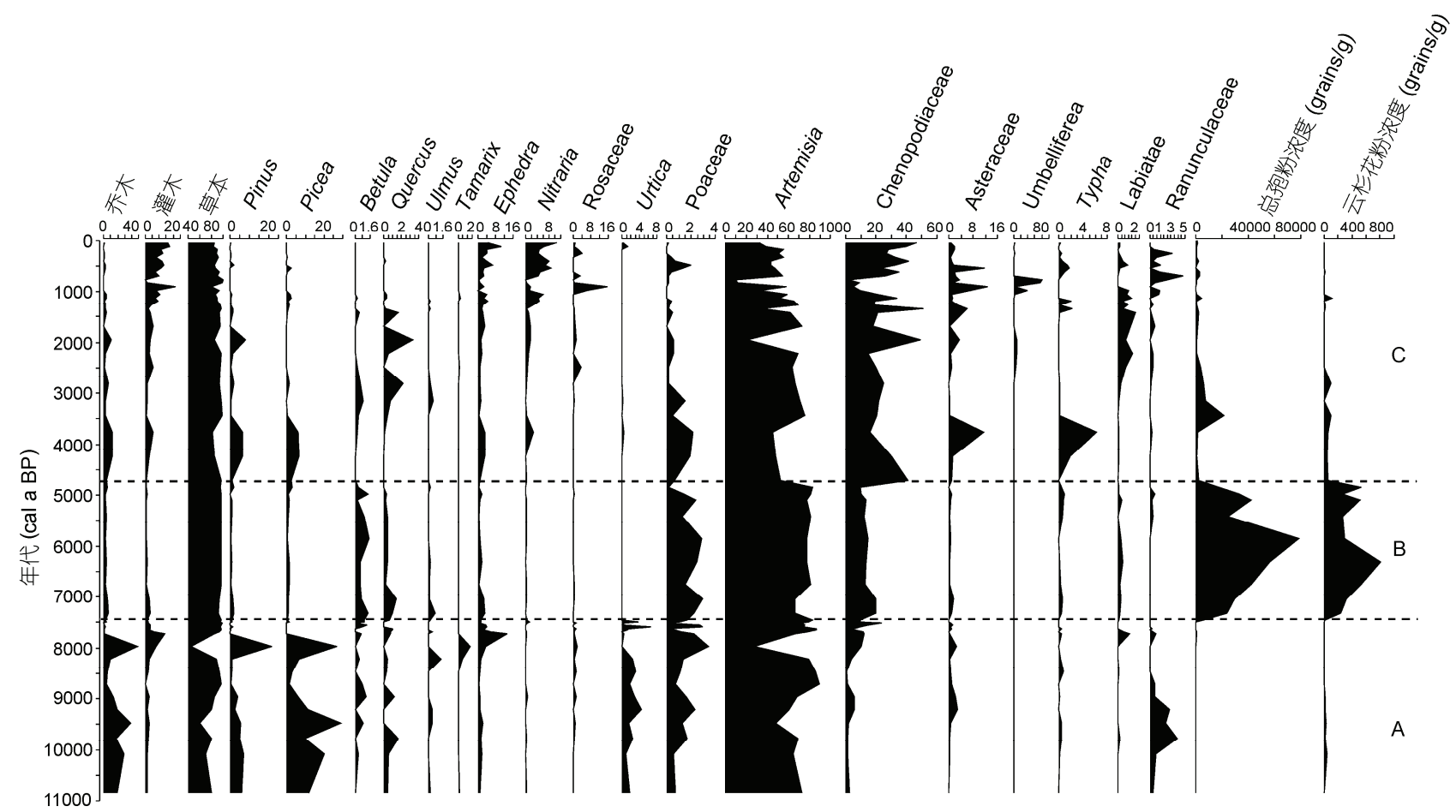

图 5 QTH02 剖面主要孢粉百分比及浓度图

该剖面狍粉组合分为 A, B, C 三个孢粉带. 该剖面花粉谱来源于文献 $[21,22]$ 
新世最高值. 带 $\mathrm{C}(4.7 \sim 0 \mathrm{cal} \mathrm{ka} \mathrm{BP})$, 孢粉组合以草本 植物为主, 草本植物的百分含量平均为 $90 \%$. 总狍 粉浓度相对于带 B 减少, 平均为 2242 grains $/ \mathrm{g}$. 乔木 花粉百分含量较少, 乔木花粉浓度为 58 grains/g. 高 属花粉百分含量有所下降; 藜科花粉平均百分含量 增加至 50\%. 菊科(Asteraceae)、白刺、麻黄花粉百分 含量相对于其他狍粉带有所增加, 分别平均为 $2.8 \%$,

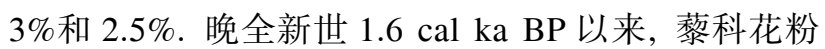
平均百分含量增加至 $30 \%$, 麻黄花粉平均百分含量 增加至 5\%, 均达到了全新世最高值.

\subsection{QTL-03 剖面全新世抱粉组合}

QTL-03 剖面也位于猪野泽中部(图 3), 剖面狍粉 分析和年代测定由 Zhao 等人 ${ }^{[23]}$ 完成. 该剖面 88 个孢 粉样品中, 鉴定出 50 个孢粉种类, 可以将该剖面狍 粉组合分为 4 个孢粉带(图 6). 带 $\mathrm{A}(7.2 \sim 5.2 \mathrm{cal} \mathrm{ka}$ BP), 孢粉组合主要由蒿属、藜科和禾本科组成. 蒿
属百分含量在 $60 \%$ 70\% 之间; 藜科和禾本科平均百 分含量为 $25 \%$ 和 $15 \%$. 该段狍粉总浓度平均可以达 到 30000 40000 grains/g. 带 B(5.2 4.3 cal ka BP), 孢 粉组合著科花粉含量较高, 平均百分含量为 $50 \%$; 蒿属花粉百分含量在 $20 \%$ 40\%之间. 菊科花粉最高 可以达到 $80 \%$. 毛茛科(Ranunculaceae) 和麻黄花粉百 分含量均达到全新世期间的最高值. 该段总花粉浓 度平均为 1000 grains $/ \mathrm{g}$. 带 $\mathrm{C}(4.3 \sim 3.5 \mathrm{cal} \mathrm{ka} \mathrm{BP})$, 蒿属 花粉百分含量增加, 平均为 $87 \%$; 㢣科花粉百分含量 平均为 $15 \%$; 禾本科花粉百分含量可以达到 $10 \%$. 总 狍粉浓度在 1000 5000 grains/g 之间. 带 $\mathrm{D}(3.5 \sim 0 \mathrm{cal} \mathrm{ka}$ BP), 孢粉组合蒿属百分含量较低, 大多在 10\% 20\% 之间. 白刺花粉百分含量较高, 平均为 $32 \%$. 根据䓠 科和菊科花粉的变化, 可以将该带分为两部分, 3.5 3.0 cal ka BP 期间, 菊科花粉百分含量高, 平均 为 95\%，总狍粉浓度在 500 3000 grains/g 之间. 3000 $0 \mathrm{cal}$ a BP 期间, 孢粉组合中藜科花粉含量较高, 平

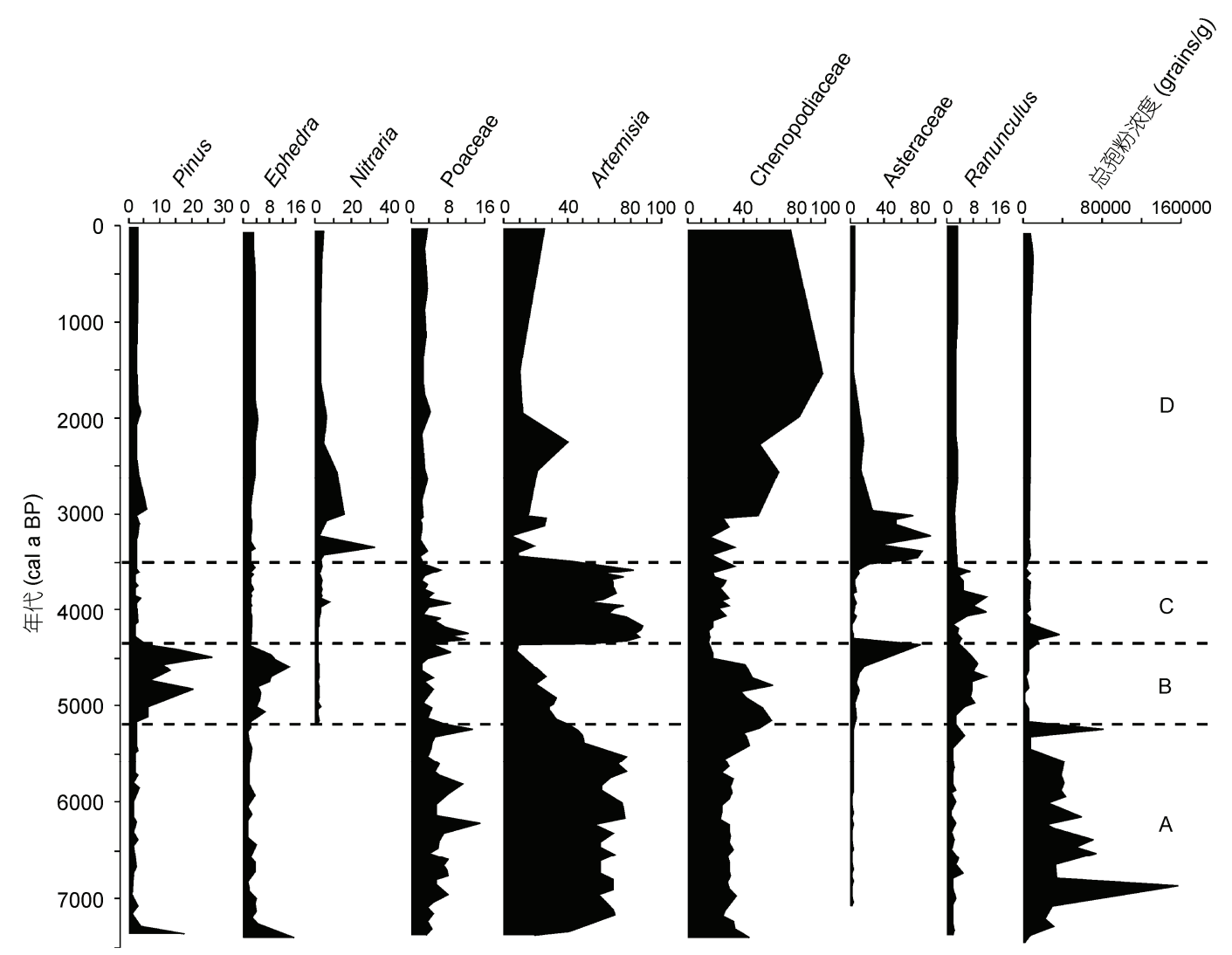

图 6 QTL-03 剖面主要孢粉百分比及浓度图

该剖面孢粉组合分为 A, B, C, D 四个孢粉带. 该剖面花粉谱来源于文献[23] 
均为 $70 \%$, 总孢粉浓度小于 600 grains $/ \mathrm{g}$.

\section{3 三角城剖面全新世狍粉组合}

三角沉全新世剖面位于猪野泽的西部(图 3), 孢 粉分析和年代测定由 Chen 等人 ${ }^{[24]}$ 完成. 该剖面 232 个孢粉样品中, 鉴定出超过 50 个孢粉种类, 可以将该 剖面孢粉组合分为 3 个带(图 7). 带 $\mathrm{A}(11.6 \sim 7.1 \mathrm{cal} \mathrm{ka}$ BP), 孢粉组合针叶树百分含量较高, 其中圆柏属、云 杉属和松属百分含量总和在 $50 \%$ $90 \%$ 之间. 阔叶树 百分含量在 $1 \%$ 11\%之间, 薕类狍子百分含量平均 为 $4 \%$. 灌木和草本植物花粉的百分含量分别为 1\% 12\%和 $2 \%$ 18\%. 该段总狍粉浓度较高, 峰值在 2000 3000 grains/g 之间, 平均为 400 1500 grains/g. 带 B(7.1 3.8 cal ka BP), 孢粉组合以草原和荒漠植物 为主, 针叶树花粉百分含量低. 灌木花粉平均为 $10 \%$, 在个别层位可达 70\%(5.5 cal ka BP), 草原植被 花粉百分含量平均为 $20 \%$. 白刺花粉百分含量相对 上一孢粉带有大幅度增加, 最高值可以达到 $90 \%$.
该段总狍粉浓度平均值为全新世期间的最低值. 带 $\mathrm{C}(3.8 \sim 0 \mathrm{cal} \mathrm{ka} \mathrm{BP})$, 总狍粉浓度变化较大, 范围在 100 6000 克/粒. 孢粉组合可以被分为两种类型, 这 两种类型分别和带 A 与带 B 相似. 2.4 1.9 cal ka BP 和 1.1 0.5 cal ka BP 期间, 总孢粉浓度较高, 孢粉组 合类似于带 $\mathrm{A}$, 其中针叶树百分含量在 38\% $80 \%$ 之 间, 水生植物香蒲 (Typha) 含量相对较高. 在该段的 其他层位, 总狍粉浓度较低, 孢粉组合类似与带 $\mathrm{B}$, 草本植物和旱生灌木百分含量相对较高, 水生植物 含量较低, 针叶树花粉含量在 $11 \%$ 70\%, 主要由圆 柏属组成.

\section{4 红水河剖面全新世狍粉组合}

红水河剖面分为晚冰期-早全新世剖面和全新 世剖面, 两个剖面相距 $1 \mathrm{~km}$, 孢粉分析和年代测定 由 Zhang 等人 ${ }^{[40]}$ 和 $\mathrm{Ma}$ 等人 ${ }^{[41]}$ 完成. 红水河晚冰期 早全新世剖面可以分为 3 个孢粉带(图 8). 带 $\mathrm{A}(13.6$ $12.2 \mathrm{cal} \mathrm{ka} \mathrm{BP})$, 花粉组合以草本植物为主, 主要有

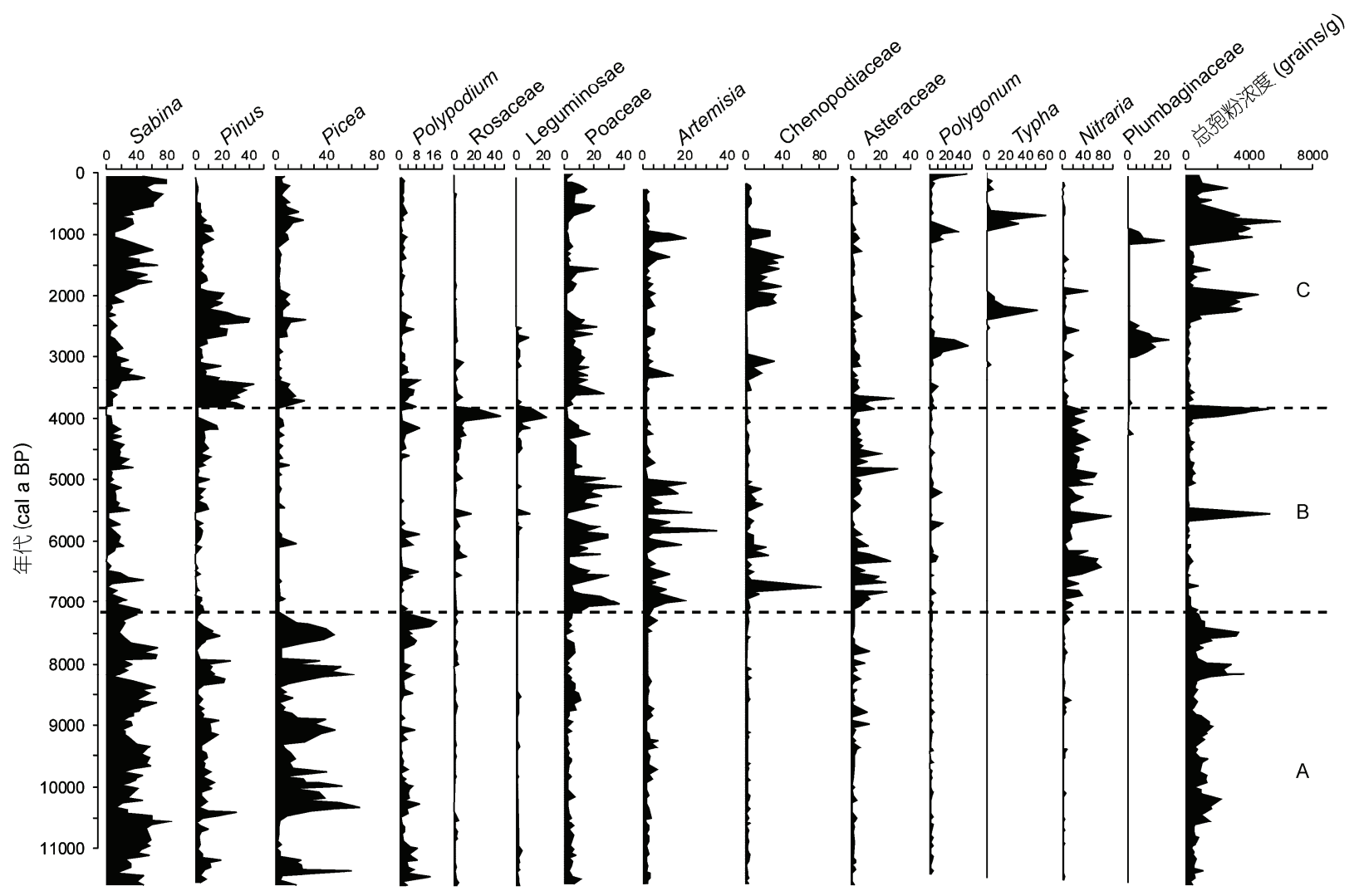

图 7 三角城剖面主要孢粉百分比及浓度图

该剖面狍粉组合分为 A, B, C 三个孢粉带. 该剖面花粉谱来源于文献[24] 


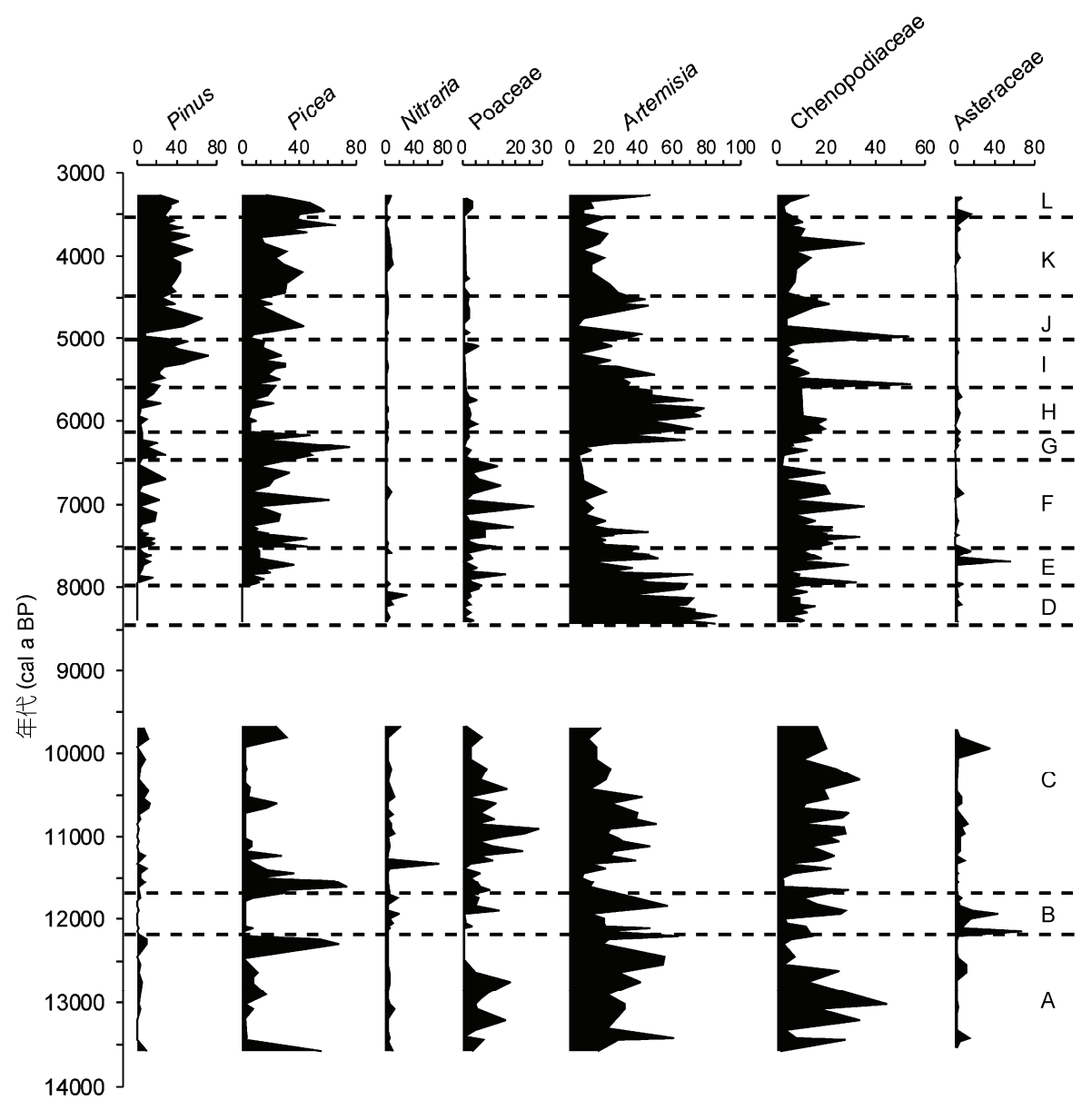

图 8 红水河剖面主要孢粉百分比图

该剖面狍粉组合为 A L 12 个狍粉带, 红水河剖面分为晚冰期-早全新世和全新世 2 个剖面, 该孢粉图将 2 个剖面孢粉组合拼接显示, 2 个剖面 上均不包含 9.5 8.5 cal BP 期间沉积物, 所以该段狍粉百分比为空值, 该剖面花粉谱来源于文献[40,41]

蒿属、藜科和禾本科; 乔木花粉含量较高, 主要为云 杉属和松属. 带 B(12.2 11.6 cal ka BP), 乔木花粉含 量下降显著, 狍粉组合以草本植物为主, 其中蒿属 和菊科花粉平均百分含量分别为 $27.8 \%$ 和 $21 \%$, 愁科 花粉平均百分含量为 $14.6 \%$. 带 $\mathrm{C}(11.6 \sim 9.7 \mathrm{cal} \mathrm{ka}$ BP), 孢粉组合仍以蒿属、藜科和禾本科为主, 但乔 木植物花粉含量较高, 以云杉属和松属为主.

红水河全新世剖面共分为 9 个孢粉带(图 8). 带 $\mathrm{D}(8450$ 7950 cal a BP $)$, 总孢粉浓度较低, 草本植物 花粉百分含量较高, 蒿属花粉平均百分含量为 $62.52 \%$, 藜科花粉平均为 $6.92 \%$. 带 $\mathrm{E}(7950 \sim 7500 \mathrm{cal} \mathrm{a} \mathrm{BP})$, 总狍粉浓度较上一段较高, 草本植物花粉含量减少, 水生植物香蒲的百分含量增加. 带 F(7500 6490 cal a $\mathrm{BP})$, 总狍粉浓度达到了本剖面最高值, 鉴定出的狍
粉种类也较多, 松属、麻黄属、云杉属、禾本科和藜科 花粉的平均百分含量分别为 $8.36 \%, 5.73 \%, 19.18 \%$, $15.27 \%$ 和 $15.27 \%$. 该段针叶树花粉平均百分含量从 狍粉带 E 的 18.00\%增加至 31.09\%. 带 G(6490 6290 cal a BP), 总狍粉浓度较高, 以云杉属为代表的针叶 树花粉含量增加幅度较大, 云杉属花粉从百分含量 从狍粉带 F 的 $19.18 \%$ 增加至 49.50\%. 带 H(6290 $5670 \mathrm{cal} \mathrm{a} \mathrm{BP})$, 总狍粉浓度较低, 蒿属和藜科花粉 百分含量较高, 分别平均为 $53.16 \%$ 和 $10.77 \%$. 带 I(5670 5010 cal a BP), 总孢粉浓度较低, 针叶树 花粉含量较高, 松属和云杉属百分含量平均为 $35.17 \%$ 和 $17.33 \%$. 带 $\mathrm{J}(5010 \sim 4470 \mathrm{cal}$ a BP), 总孢粉 浓度较低, 蒿属和藜科平均百分含量分别为 $25.55 \%$ 和 $20.14 \%$. 松属花粉平均为 $29.14 \%$, 云杉属平均为 
$14.86 \%$. 带 $\mathrm{K}(4470 \sim 3510$ cal a BP $)$, 总孢粉浓度较 低, 针叶树花粉含量较高, 平均为 $68.07 \%$. 带 L(3510 3230 cal a BP), 孢粉组合中香蒲和眼子菜 (Potamogeton)百分含量较高, 显示了水生环境.

\section{4 亚洲季风西北边缘区流域性狍粉记录揭 示的全新世气候变化模式}

研究区位于我国干旱-半干旱地区, 流域内河 湖相沉积序列随着流域水循环状态的改变, 变化很 大, 河湖相沉积序列中往往伴随沉积相变和沉积间 断, 这种沉积相变和沉积间断又会对沉积物中的孢 粉组合产生影响, 本文作者在研究 QTH02 剖面沉 积物粒度组成和花粉组合之间的关系时, 就发现了 这个问题 ${ }^{[22]}$. 本文在探讨不同剖面孢粉组合的关系 时, 为了避免沉积相变化对狍粉指示意义的影响, 采用以云杉花粉百分比含量和浓度为参照的检验方 法, 以避免沉积相变对孢粉指示意义的影响. 根据 石羊河流域现代狍粉传播过程研究 ${ }^{[44]}$, 云杉花粉在 流域中下游地区主要受河流传播, 风力传播的云杉 花粉在该流域中下游地区沉积物中所占比分较小. 据此, 该流域河湖相地层中云杉花粉的浓度和百分 含量要显著高于风成沉积物地层. 在环境突变的情 况下, 河湖相沉积物被风成沉积物打断, 云杉花粉 的百分含量及浓度在河湖相地层和风成沉积地层是 差异非常大, 所以通过云杉花粉含量及浓度的变化 程度可以判断出沉积相是否发生剧烈变化. 根据猪 野泽 3 个全新世剖面狍粉组合对比研究, $7.0 \mathrm{cal} \mathrm{ka}$ BP 以来 QTH02 和 QTL-03 剖面的狍粉组合相似度

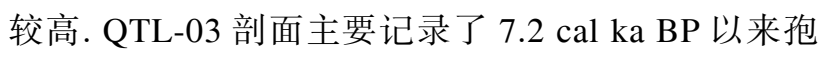
粉组合的变化, 中全新世(7.2 5.2 cal ka BP)期间, 孢粉组合以蒿属、莍科和禾本科为主, 总狍粉浓度 较高, 平均可以达到 30000 40000 grains/g, Zhao 等 人 ${ }^{[23]}$ 认为该时期为全新世气候适宜期. QTH02 剖面 中全新世(7.4 4.7 cal ka BP)期间, 总狍粉浓度达到 全新世最高值, 平均为 38634 grains/g, 狍粉组合也 是以蒿属和藜科花粉为主. 中全新世 $(\sim 5.0 \mathrm{cal} \mathrm{ka}$ $\mathrm{BP})$ 以后, 两个剖面均显示出总狍粉浓度降低的现 象, 伴随着泰科、白刺、麻黄等旱生植物的增加, 显 示了中全新世过后的干旱化趋势. 三角城剖面狍粉 记录显示早全新世(11.6 7.1 cal ka BP)总狍粉浓度 高, 以云杉属、松属和圆柏属为代表的乔木花粉百
分含量较高. 中全新世期间(7.1 3.8 cal ka BP)三角 城剖面总狍粉浓度处于全新世最低, 以灌木和草本 植物花粉为主. 晚全新世期间该剖面狍粉组合变化 较大, 各种狍粉组合交替出现, 显示出气候的不稳 定性. Chen 等人 ${ }^{[24]}$ 根据该剖面狍粉组合特征, 得出 早全新世期间石羊河流域上游乔木植被发育较好, 气候湿润. QTH02 剖面早全新世期间(11.0 7.4 cal ka BP)以云杉属和松属为代表的乔木花粉百分含量 达到全新世期间的最高值, 从乔木花粉百分含量来 看三角城剖面与 QTH02 剖面具有一定相似性. 朱 艳等人 ${ }^{[44]}$ 研究了石羊河流域的空气、表土、河水和 河床冲积物中的狍粉组合特征, 其结果显示该流域 河流搬运狍粉的能力较风力强, 河水搬运的狍粉对 中下游河床冲积物及河水孢粉谱的贡献量非常大, 并得出在终端湖沉积物中以云杉属为代表的山地乔 木花粉主要受河水搬运. $\mathrm{Lu}$ 等人 ${ }^{[45]}$ 研究了青藏高原 及临近区域表土花粉中云杉属和冷杉(Abies)花粉的 分布特征, 结果显示这两种花粉主要分布在海拔 2500 4000 m, 年均温 $-1 \sim 10{ }^{\circ} \mathrm{C}$, 年均降雨量 $450 \sim 850 \mathrm{~mm}$ 的区域, 这与猪野泽的气候特征明显 不符，也证明了该区域河水对云杉属花粉的搬运作 用. 云杉属植物属于喜冷湿的植物 ${ }^{[46]}$, 云杉属花粉 气候响应面分析结果也显示, 该花粉丰度受到湿度 变化的控制 ${ }^{[47]}$, 这些说明猪野泽云杉属花粉的变化 主要受控于上游祁连山区气候的湿润程度, 上游地 区降水增加会使云杉林扩张, 同时水量增加也可以 搬运更多的云杉属花粉到终端湖沉积. QTH02 和三 角城剖面早全新世期间较高的云杉花粉及其他乔木 百分含量, 共同指示了早全新世期间石羊河上游地 区气候较湿润，而中全新世期间三角城剖面与 QTH02 和 QTL-03 剖面孢粉组合差异非常大, 是什 么造成了这种差异呢? 根据图 3 可知, QTH02 和 QTL-03 相距较近位于猪野泽中部地区, 而三角城 剖面位于猪野泽西部边缘地区与其他两个剖面相隔 较远. Xu 等人 ${ }^{[48]}$ 研究了岱海湖底不同位置表层沉积 物狍粉组合特征, 结果显示湖泊不同位置狍粉组合 会有差异, 这种差异主要受到湖岸附近植被的影 响. Huang 等人 ${ }^{[49]}$ 研究了博斯腾湖表层沉积物狍粉 组合特征, 结果表明湖泊中心位置总狍粉浓度较其 他位置高, 河口区云杉属花粉百分含量较高, 这由 于云杉属花粉主要受河水搬运. 以上两项研究表明 
湖泊不同位置沉积物孢粉组合存在差异, 三角城剖 面与其他两个剖面在猪野泽的位置差异较大, 这可 能是造成中全新世狍粉组成不同的原因之一. 除此 以外, 该区域湖泊地貌研究结果显示全新世期间猪 野泽岸堤海拔高度未超过 $1308 \mathrm{~m}$, 中全新世湖泊水 位海拔高度在 1306 1308 $\mathrm{m}$ 之间 ${ }^{[38,39]}$, QTH02 剖面 海拔 1309 m, QTL-03 剖面海拔 1302 m, 这两个剖面 中全新世沉积大概距剖面顶部 $3 \mathrm{~m}$ 左右, 所以 QTH02 和 QTL-03 剖面位置中全新世期间的海拔应 该为 1306 和 $1299 \mathrm{~m}$ 左右, 所以中全新世期间这两 个剖面基本处于猪野泽湖泊水位以下. 而三角城剖 面海拔 $1320 \mathrm{~m}$, 中全新世沉积物距剖面顶部 3 4 m 左右, 所以三角城剖面位置中全新世期间海拔 1316 1317 m 左右, 这个高度远远超过了中全新世 期间猪野泽的湖泊水位高度, 三角城剖面位置中全 新世期间并不处于猪野泽湖盆内部, 而是处于猪野 泽湖泊周边区域, 所以其全新世沉积物狍粉组合可 能会受到局地地貌、水文、植被条件的影响, 会导 致三角城剖面所记录的孢粉组合变化特征与湖盆内 部狍粉组成很大. 所以, 受剖面位置的影响, 中全 新世期间三角城剖面与其他两个剖面的孢粉组合特 征差异较大. 综合 QTH02 和 QTL-03 剖面中全新世 (约 7.0 5.0 cal ka BP) 期间总狍粉浓度较高和云杉花 粉浓度较高的特征, 得出该流域中全新世期间气候 适宜, 植被覆盖度较高, 该阶段乔木花粉百分含量 较少, 可能是由于整个流域草本植物繁盛, 所以上 游水流搬运来得乔木花粉所占比较大大减少, 但是 从云杉花粉浓度增加可以看出, 上游携带来的云杉 花粉量并没有减小.

红水河剖面位于石羊河中游地区，红水河晚冰 期-早全新世剖面 12.2 11.6 cal ka BP 期间, 以云杉 属为代表的乔木花粉含量显著下降, 说明上游山地 气候较干, 可能对应了亚洲季风区以季风衰退为特 征 YD 事件 ${ }^{[50]}$. 全新世开始以后, 11.6 9.7 cal ka BP 期间, 云杉属和松属花粉增加显著, 说明上游地区 开始变湿润, 这可能与早全新世亚洲季风增强有关. 红水河全新世剖面揭示了 8.5 3.0 cal ka BP 期间孢 粉组合的变化, 该剖面分为 9 个孢粉带, 其中中全新 世 7.5 3.5 cal ka BP 期间, 大部分层位以云杉属为主 的乔木花粉浓度较高, 说明中全新世上游地区降水 较多、气候湿润, 不过在中全新世期间, 各种花粉含
量存在显著波动, 这可能代表了千年尺度的气候波 动. $3.5 \mathrm{cal} \mathrm{a} \mathrm{BP}$ 以后狍粉组合以香蒲和眼子菜花粉 含量较高, 指示了静水环境.

石羊河流域位于亚洲季风的西北边缘区，对比 该流域 4 个全新世孢粉组合的特征指标与亚洲季风 区和中亚西风带控制区典型全新世记录的关系，可 以探讨季风边缘区全新世气候变化的机制. 在亚洲 季风区选择了不同位置可靠定年的 3 个全新世石笋 记录(董歌洞 ${ }^{[10]}$ 、和尚洞 ${ }^{[11]}$ 、 Qunf 洞 $^{[12]}$ ), 中亚西风 带控制区选择了两个典型的全新世湖泊记录(博斯腾 湖 $^{[16]}$ 、乌伦古湖 $\left.{ }^{[51]}\right)$, 并引用了中亚干旱区 11 个湖泊 平均的全新世湿润指数记录 ${ }^{[16]}$. 根据图 9 中指标对 比可知, 石羊河流域 QTH02、三角城和红水河剖面 均显示了早全新世期间云杉花粉百分含量较高, 指 示了石羊河上游地区气候较湿润, 这与石笋记录指 示的早全新世亚洲季风较强相符, 说明早全新世期 间石羊河上游气候受到亚洲季风的影响. 中全新世 期间 QTH02 和 QTL-03 剖面总孢粉浓度达到了全新 世最高值, QTH02 剖面较高的云杉属花粉浓度也说 明上游地区较湿润的气候, 石羊河中游地区红水河 全新世剖面 7.5 3.5 cal ka BP 期间较高的云杉属花粉 含量也证明了这一点, 终端湖地区较高的总孢粉浓 度和云杉属花粉浓度, 说明全流域乔木和草本植被 均发育较好, 中全新世环境可能较早全新世湿润, 这与中亚干旱区中全新世气候适宜期相似。由 QTH02 和 QTL-03 剖面孢粉组合可知, 晚全新世 5.0 cal ka BP 以来, 该流域呈现出干旱化趋势, 中游地 区 $3.5 \mathrm{cal} \mathrm{ka} \mathrm{BP}$ 开始也出现静水环境, 可能与上游地 区来水量减少有关，该流域晚全新世干旱化趋势可 能受到亚洲季风减弱的影响. 综上所述, 石羊河流 域全新世气候变化受到亚洲季风和西风带气流的共 同影响, 体现了全新世气候变化季风模式和西风模 式的共同特点, 说明了亚洲季风边缘区气候变化的 复杂性, 继续探讨亚洲季风西北边缘区气候变化的 机制, 还需要进一步研究该区域更高分辨率的古气 候记录, 并借助模拟手段来探讨全新世季风、西风气 候动力学.

根据本项研究中同一流域 4 个不同位置的全新 世孢粉组合对比, 可以看出流域不同位置狍粉组合 差异较大, 使用单一孢粉组合进行古环境讨论, 其 真实性和客观性都会受到限制, 所以进行流域性古 


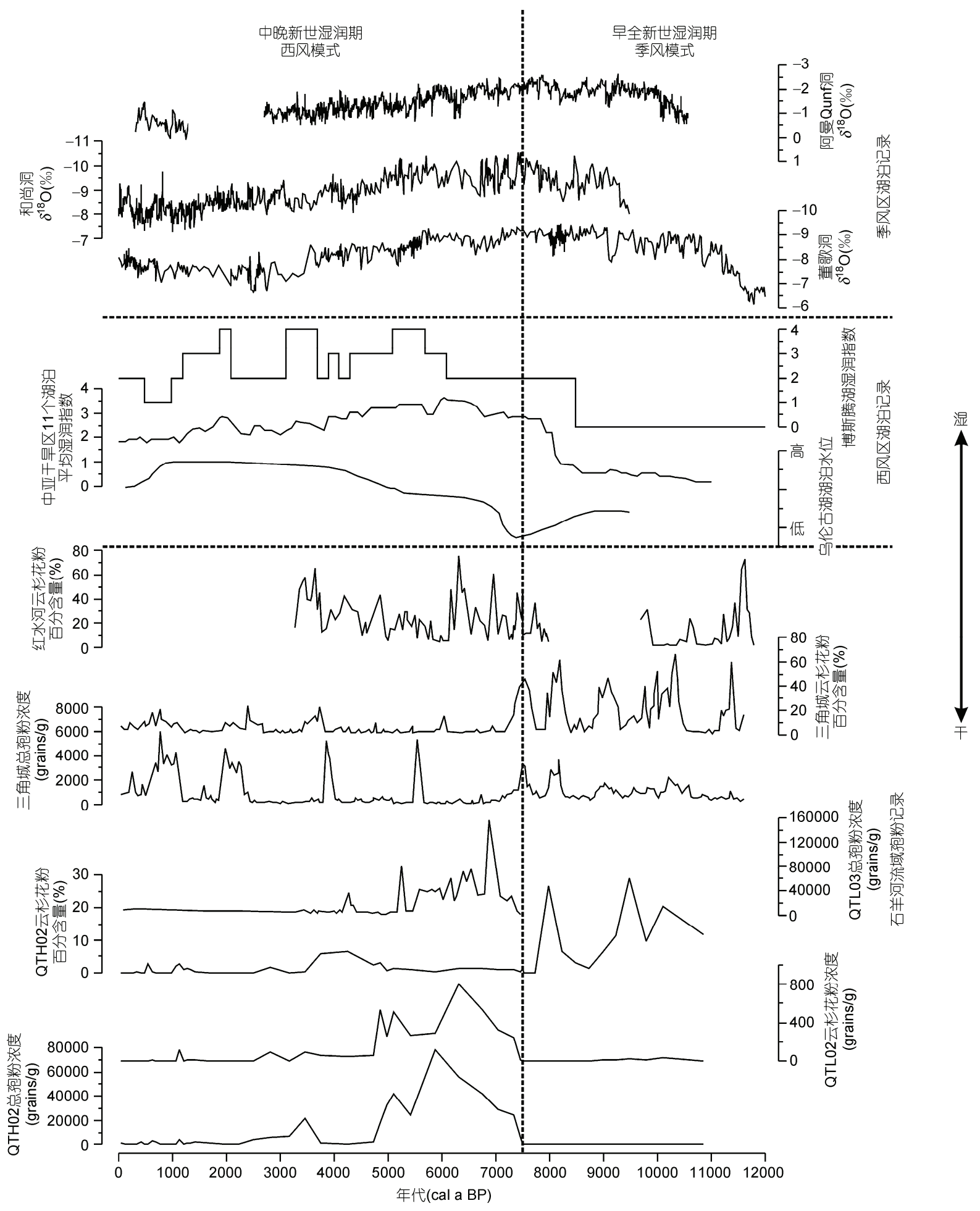

图 9 石羊河流域不同位置全新世狍粉组合的典型指标与亚洲季风区全新世石笋记录及中亚西风带控制区湖泊记录对比图

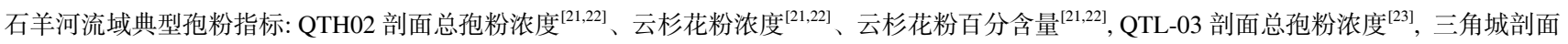
总敄粉浓度 ${ }^{[24]}$ 、云杉花粉百分含量 ${ }^{[24]}$, 红水河剖面云杉花粉百分含量 ${ }^{[40,41]}$. 亚洲季风区不同位置石笋记录: 董歌洞 ${ }^{[10]}$ 、和尚洞 ${ }^{[11] 、 Q u n f ~}$ 洞 $^{[12]}$ 石笋的全新世亚洲季风记录. 中亚西风带控制区湖泊记录: 博斯腾湖湿润指数记录 ${ }^{[16]}$, 乌伦古湖湖泊水位变化记录 ${ }^{[51]}$, 中亚地区 11 个湖泊的 平均湿润指数记录 ${ }^{[16]}$ (11 个湖泊包括: 凡湖, 咸海, 伊塞克湖, 乌伦古湖, 博斯腾湖, 巴彦淖, 塔莫尔湖, 库苏古尔淖, 居延海, 干淖, 呼伦湖) 
植被、古气候重建, 需要进一步考虑研究点所处位置 对重建工作的影响. 本项研究并没有使用孢粉学中 常用的蒿属和僽科的比值作为指标探讨古气候, 因
为该流域 4 个剖面全新世期间沉积相变明显, 沉积 相变化可以导致孢粉的明显变化, $\mathrm{A} / \mathrm{C}$ 比的环境意义 不明显. 和沉积学方面给予本文开创性的意见和建议.

\section{参考文献}

1 PAGES Scientific Steering Committee. Science Plan and Implementation Strategy. IGBP Report No. 57, IGBP. 2009

2 He Y, Wilfred H, Zhang Z, et al. Asynchronous Holocene climatic change across China. Quat Res, 2004, 61: 52-63

3 An Z S, Porter S C, Kutzbach J E, et al. Asynchronous Holocene optimum of the East Asian monsoon. Quat Sci Rev, 2000, 19: 743-762

4 An C, Feng Z, Barton L. Dry or humid? Mid-Holocene humidity changes in arid and semi-arid China. Quaternary Sci Rev, 2006, 25: 351-361

5 Feng Z D, An C B, Tang L Y, et al. Stratigraphic evidence of megahumid mid-Holocene climate in the western part of the Chinese Loess Plateau. Global Planet Change, 2004, 43: 145-155

6 Tao S, Chen L. A review of recent research on the East Asian summer monsoon in China. In: Chang C P, Krishnamurti T N, eds. Monsoon Meteorology. Oxford: Oxford University Press, 1987. 60-92

7 Wang B, Lin H. Rainy Season of the Asian-Pacific Summer Monsoon. J Clim, 2002, 15: 386-398

8 Hong Y, Hong T, Lin Q, et al. Inverse phase oscillations between the East Asian and Indian Ocean summer monsoons during the last 12000 years and paleo-El Niño. Earth Planet Sci Lett, 2005, 231: 337-346

9 杨琰, 袁道先, 程海, 等. 未次冰消期亚洲季风突变事件的精确定年：以贵州衙门洞石笋为例. 中国科学：地球科学, 2010, 40: 199-210

10 Dykoski C A, Edwards R L, Cheng H, et al. A high-resolution, absolute-dated Holocene and deglacial Asian monsoon record from Dongge Cave, China. Earth Planet Sci Lett, 2005, 233: 71-86

11 Hu C, Henderson G M, Huang J, et al. Quantification of Holocene Asian monsoon rainfall from spatially separated cave records. Earth Planet Sci Lett, 2008, 266: 221-232

12 Fleitmann D, Burns S J, Mudelsee M, et al. Holocene Forcing of the Indian Monsoon Recorded in a Stalagmite from Southern Oman. Science, 2003, 300: 1737-1739

13 中国科学院《中国自然地理》编辑委员会. 中国自然地理气候. 北京: 科学出版社, 1984. 1-30

14 李吉均. 中国西北地区晚更新世以来环境变迁模式. 第四纪研究, 1990, 3: 197-204

15 Herzschuh U. Palaeo-moisture evolution in monsoonal Central Asia during the last 50000 years. Quat Sci Rev, 2006, 25: 163-178

16 Chen F, Yu Z, Yang M, et al. Holocene moisture evolution in arid central Asia and its out-of-phase relationship with Asian monsoon history. Quat Sci Rev, 2008, 27: 351-364

17 Li X, Zhou W, An Z, et al. The vegetation and monsoon variations at the desert-loess transition belt at Midiwan in northern China for the last $13 \mathrm{ka}$. Holocene, 2003, 13: 779-784

18 Xiao J, Xu Q, Nakamura T, et al. Holocene vegetation variation in the Daihai Lake region of north-central China: A direct indication of the Asian monsoon climatic history. Quat Sci Rev, 2004, 23: 1669-1679

19 Jiang W Y, Liu T S. Timing and spatial distribution of Mid-Holocene drying over northern China: Response to a south-eastward retreat of the East Asian monsoon. J Geophys Res, 2007, 112: D24111, doi:10.1029/2007JD009050

20 Wen R, Xiao J, Chang Z, et al. Holocene precipitation and temperature variations in the East Asian monsoonal margin from pollen data from Hulun Lake in northeastern Inner Mongolia, China. Boreas, 2010, 39: 262-272

21 Li Y, Wang N, Cheng H, et al. Holocene environmental change in the marginal area of the Asian monsoon: a record from Zhuye Lake, NW China. Boreas, 2009, 38: 349-361

$22 \mathrm{Li} \mathrm{Y}$, Wang N, Morrill C, et al. Environmental change implied by the relationship between pollen assemblages and grain-size in N.W Chinese lake sediments since the Late Glacial. Rev Palaeobot Palynology, 2009, 154: 54-64

23 Zhao Y, Yu Z, Chen F H, et al. Holocene vegetation and climate change from a lake sediment record in the Tengger Sandy Desert, northwest China. J Arid Environ, 2008, 72: 2054-2064

24 Chen F H, Cheng B, Zhao Y, et al. Holocene environmental change inferred from a high-resolution pollen record, Lake Zhuyeze, arid 
China. Holocene, 2006, 16: 675-684

38 Zhang H C, Peng J L, Ma Y Z, et al. Late Quaternary palaeolake levels in Tengger Desert, NW China. Paleogeogr Paleoclimatol Paleoecol, 2004, 211: 45-48

39 隆浩, 王乃昂, 李育, 等. 猪野泽记录的季风边缘区全新世中期气候环境演化历史. 第四纪研究, 2007, 27: 371-381

40 Zhang H C, Ma Y Z, Wünnemann B. A Holocene climatic record from arid northwestern China. Paleogeogr Paleoclimatol Paleoecol, 2000, 162: 389-401

41 Ma Y, Zhang H, Pachur H J, et al. Late Glacial and Holocene vegetation history and paleoclimate of the Tengger Desert, northwestern China. Chinese Sci Bull, 2003, 48: 1457-1463 terpretation. Chinese Sci Bull, 2003, 48: 1439-1445

43 陈发虎, 朱艳, 李吉均, 等. 民勤盆地湖泊沉积记录的全新世千百年尺度夏季风快速变化.科学通报, 2001, 46: 1414-1419

44 朱艳, 程波, 陈发虎，等. 石羊河流域现代狍粉传播研究. 科学通报, 2004, 49: 15-21

45 Lu H Y, Wu N Q, Yang X D, et al. Spatial pattern of Abies and Picea surface pollen distribution along the elevation gradient in the Qinghai-Tibetan Plateau and Xinjiang, China. Boreas, 2008, 37: 254-262

46 中国植被编辑委员会. 中国植被. 北京: 科学出版社, 1980. 195-197

47 孙湘君, 王琫瑜, 宋长青. 中国北方部分科属花粉-气候响应面分析. 中国科学 D 辑：地球科学, 1996, 26: 431-436

48 Xu Q, Li Y, Yang X, et al. Source and distribution of pollen in the surface sediment of Daihai Lake, inner Mongolia. Quat Int, 2005, 136: $33-45$

49 Huang X, Zhou G, Ma Y, et al. Pollen distribution in large freshwater lake of arid region: A case study on the surface sediments from Bosten Lake, Xinjiang, China. Front Earth Sci China, 2010, 4: 174-180

50 庞有智, 张虎才，常凤琴，等. 腾格里沙漠南缘末次冰消期气候不稳定性记录. 第四纪研究, 2010, 30: 69-79

51 Liu X, Herzschuh U, Shen J, et al. Holocene environmental and climatic changes inferred from Wulungu Lake in northern Xinjiang, China. Quat Res, 2008, 70: 412-425 